\title{
Addressing the unmet needs of patients with persistent negative symptoms of schizophrenia: emerging pharmacological treatment options
}

This article was published in the following Dove Press journal:

Neuropsychiatric Disease and Treatment

8 May 2014

Number of times this article has been viewed

\author{
Pierre Chue' \\ Justine K Lalonde ${ }^{2}$ \\ 'Department of Psychiatry, University \\ of Alberta, Edmonton, AB, Canada; \\ ${ }^{2}$ Roche SAS, Medical Affairs \\ Department, Boulogne-Billancourt, \\ France
}

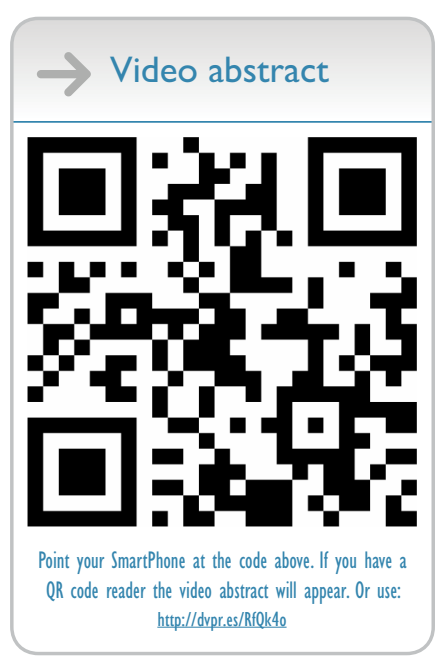

Correspondence: Pierre Chue 3rd Floor, 9942-108 St, Edmonton, Alberta, Canada T5K 2J5

Tel +l 7803427944

Fax +I 7804259317

Email pchue@ualberta.ca

\begin{abstract}
The negative symptoms of schizophrenia represent an impairment of normal emotional responses, thought processes and behaviors, and include blunting or flattening of affect, alogia/aprosody, avolition/apathy, anhedonia, and asociality. Negative symptoms contribute to a reduced quality of life, increased functional disability, increased burden of illness, and poorer long-term outcomes, to a greater degree than positive symptoms. Primary negative symptoms are prominent and persistent in up to $26 \%$ of patients with schizophrenia, and they are estimated to occur in up to $58 \%$ of outpatients at any given time. Negative symptoms respond less well to medications than positive symptoms, and to date treatment options for negative symptoms have been limited, with no accepted standard treatment. Modest benefits have been reported with a variety of different agents, including second-generation antipsychotics and add-on therapy with antidepressants and other pharmacological classes. Recent clinical research focusing on negative symptoms target novel biological systems, such as glutamatergic neurotransmission. Different approaches include: enhancing N-methyl-D-aspartate receptor function with agents that bind directly to the glycine ligand site or with glycine reuptake inhibitors; influencing the metabotropic glutamate receptor (mGluR2/3) with positive allosteric modulators; and stimulating nicotinic acetylcholine receptors. In conclusion, the lack of clearly efficacious pharmacological treatments for the management of negative symptoms represents a significant unmet need, especially considering the importance of these symptoms on patient outcomes. Hence, further research to identify and characterize novel pharmacological treatments for negative symptoms is greatly needed.
\end{abstract}

Keywords: negative symptoms, schizophrenia, NMDA receptor, glycine reuptake inhibitors, metabotropic glutamate receptor-2 (mGluR2), 7-alpha nicotinic acetylcholine receptor agonists

\section{Introduction}

Negative symptoms of schizophrenia represent a deficit or impairment of normal emotional responses, thought processes, and behaviors affecting communication and social interaction. ${ }^{1}$ Negative symptoms range from expressive deficits such as blunting or flattening of affect and alogia/aprosody, to motivational deficits characterized by avolition/ apathy, anticipatory anhedonia, and asociality. ${ }^{2-5}$ In contrast to positive symptoms, negative symptoms are relatively enduring, constant, and more predictive of psychosocial impairment. ${ }^{6,7}$ Persistent negative symptoms are present in more than a quarter of patients with a first episode of psychosis ${ }^{8}$ and are associated with lower premorbid functioning, male sex, longer duration of untreated psychosis, and poorer insight. ${ }^{6,9}$ Thus, negative symptoms lead to poorer outcome, particularly if present in early psychosis, and contribute to a greater degree than positive symptoms to poorer quality of 
life, greater functional disability, and increased burden of illness. Furthermore, negative symptoms respond less well to antipsychotic medications than positive symptoms.

To date, treatment options for negative symptoms have been limited, and there is no widely accepted standard treatment. Randomized, controlled trials (RCTs) have been designed to show a specific effect on the negative symptoms of schizophrenia by recruiting patients with prominent negative symptoms and systematically minimizing confounding factors (eg, positive and depressive symptoms, extrapyramidal symptoms [EPS]). In addition, several studies have been conducted in varied patient populations without specifically recruiting patients with a negative symptom profile; these studies used different scales for assessing negative symptoms, which makes it difficult to interpret the results and translate improvements in symptom scores into clinically meaningful outcomes.

This review summarizes the published clinical trial data for emerging pharmacological treatments for negative symptoms in schizophrenic patients. A nonsystematic literature search was performed in two parts. Firstly, we performed an electronic search using MEDLINE and Embase to identify articles published up to October 2013 that evaluated emerging treatments for negative symptoms in schizophrenia. The primary search terms were "treatments", "medications", "negative symptoms", and "schizophrenia". Meta-analyses and systematic reviews were included and preferentially retained where available, based on the premise that they best captured the most robust data available; otherwise, original research articles and other articles of interest were included in this review. Secondly, we performed a search for abstracts and posters describing emerging treatments for negative symptoms presented at congresses, as well as company press releases, up to January 2014.

\section{Prevalence of negative symptoms}

There is great variability in the reported prevalence rates of negative symptoms. Discrepancies are due to differences across studies - in particular, the use of different definitions for negative symptoms. For example, if the definition used is the presence of one or more negative symptoms at any given time, regardless of etiology, severity, or duration, then the reported prevalence rates of negative symptoms in first-episode patients range from $41 \%$ to $54 \%$, and up to $58 \%$ in patients with chronic schizophrenia. ${ }^{10-12}$ In contrast, the estimated prevalence of negative symptoms ranges from $23 \%$ to $26 \%$ when using a definition of primary persistent negative symptoms, which specifies a minimum severity of symptoms, excludes comorbidities such as anxiety, depression, or EPS, and stipulates a duration of at least 12 months..$^{9,10,12,13}$

\section{Primary versus secondary negative symptoms}

Key guidelines recommend distinguishing between primary and secondary negative symptoms. According to the 2004 American Psychiatric Association (APA) guidelines for schizophrenia, "Treatment of negative symptoms begins with assessing the patient for syndromes that can cause the appearance of secondary negative symptoms. The treatment of such secondary negative symptoms consists of treating their cause, eg, antipsychotics for primary positive symptoms, antidepressants for depression, anxiolytics for anxiety disorders, or antiparkinsonian agents or antipsychotic dose reduction for extrapyramidal side effects." ${ }^{14}$

Although guidelines advocate the distinction between primary and secondary negative symptoms, they can be difficult to distinguish in clinical practice; ${ }^{3,15-18}$ indeed, primary and secondary negative symptoms may coexist. More recently, the identification of primary negative symptoms in clinical research has shifted to a symptom dimension-based approach, which is meant to simplify the heterogeneity of negative symptoms and perhaps better inform the underlying neurobiology. Several factor analyses of negative symptoms scales have shown two subdomains to be important: diminished expression and amotivation. ${ }^{4,19}$ The first study to confirm the longitudinal stability of the dimension-based approach also showed it to be more predictive of psychosocial outcomes than older categorical definitions (such as deficit syndrome). ${ }^{19}$ Another recent study showed the important contribution of the amotivation domain to poor functioning in patients early in the disease course. ${ }^{20}$

\section{Neurobiology of negative symptoms}

The neurobiological underpinnings of negative symptoms are complex and continue to be the subject of discussion and research. ${ }^{21}$ While the basis of positive symptoms may be explained by dopaminergic models, the explanatory hypotheses of negative symptoms encompass a broader array of candidate neurotransmitters and associated pathways. There is no shared common understanding of the neurobiology of negative symptoms, which may eventually be revealed as too heterogeneous a concept to unite around a single biological hypothesis, as there is for positive symptoms. Although the cellular, molecular, and circuit alterations underlying these symptoms are not clear, studies focusing on motivation, reward, working memory, and goal-oriented behavior may help shed light on the circuitry that is altered in negative symptoms, ${ }^{22,23}$ especially as these physiological functions correspond to the clinical dimension elucidated by factor analyses of negative symptoms discussed later. 
The biology of motivation has been extensively studied across species and in humans, and some key brain regions involved are the prefrontal cortex (ventromedial, orbitofrontal, and dorsolateral), the anterior cingulate, and the striatum; ${ }^{22}$ all structures are modulated by mesocortical/ mesoaccumbens dopaminergic systems and cortico-striatalthalamo-cortical loops. There is both clinical and preclinical evidence suggesting that abnormalities in information processing in these networks play an important role in the etiology of negative symptoms. ${ }^{22-26}$

These neurocircuits implicate dopamine dysregulation, as opposed to an excess of dopamine, associated with psychotic symptoms; it would appear that there is too little dopamine or sensitivity to change of dopamine input in the reward circuitry. In addition, gamma-amino butyric acid (GABA) and glutamate are key in regulating neural loops between the striatum and prefrontal cortex, as well as impacting the modulation of dopaminergic release. Specifically, hypofunction of N-methyl-D-aspartate (NMDA) receptor transmission may be responsible for functional alterations in the prefrontal cortex,${ }^{27}$ striato-ventrotegmental loops,${ }^{28-30}$ and thalamocortical projections that may be associated with negative symptoms. ${ }^{31-33}$

\section{Assessment of negative symptoms}

Assessing negative symptoms provides several benefits, including helping to tailor treatments for individual patients, and educating health care professionals, caregivers, and patients. Following the recommendations of the National Institute of Mental Health-Measurement and Treatment Research to Improve Cognition in Schizophrenia (NIMHMATRICS) report, ${ }^{34}$ new scales have been developed that attempt to incorporate an updated understanding of negative symptoms, especially the patient's inner experience and various aspects of motivation. In particular, work groups are actively field testing and refining two new measures: the Clinical Assessment Interview for Negative Symptoms (CAINS $)^{35}$ and the Brief Negative Symptom Scale (BNSS). ${ }^{36}$ Although more than 18 instruments for assessing negative symptoms exist, drug development clinical trials to date have primarily used the Positive and Negative Syndrome Scale (PANSS) negative symptoms factor score (NSFS), ${ }^{37,38}$ the Negative Symptom Assessment (NSA) scale, ${ }^{39}$ and the Schedule for the Assessment of Negative Symptoms (SANS). ${ }^{34,40}$

The management of negative symptoms is a relatively new therapeutic area, and thus many questions remain regarding the optimal trial design to evaluate these symptoms. A recent report from an international workshop describes a general consensus that in such clinical trials, ratings for negative symptoms should include a single global score. ${ }^{41}$ Moreover, these ratings should include global scores for major domains such as expressiveness and apathy/asociality. ${ }^{41}$ To achieve consistent and reliable ratings of negative symptoms over time, both the clinical setting in which the patient is managed and the medication regimen should remain stable. Functional measures should be included as key secondary end points in these clinical trials given their strong association with negative symptoms.

\section{Impact of negative symptoms on functionality}

Many patients with schizophrenia experience significant functional impairments. There is a consistent and strong correlation between both the presence and severity of negative symptoms and deleterious effects on employment, financial status, living situation, and social interaction, as well as on subjective variables such as self-esteem, distress, and satisfaction with life. ${ }^{42-46}$ Recent analyses of the Clinical Antipsychotic Trials of Intervention Effectiveness (CATIE) data demonstrate that, although both positive and negative symptoms contribute independently to functional decline, negative symptoms have a greater impact overall. ${ }^{47,48}$ Indeed, greater declines in functionality and health-related quality of life, and more lost caregiver workdays, are associated with patients with the greatest negative symptomatology. ${ }^{48}$ The magnitude of the problem is amplified by the high prevalence of negative symptoms (up to $58 \%)^{12}$ in routine clinical practice, as described previously.

\section{Impact of negative symptoms on global psychosocial functioning}

The presence of negative symptoms has been found to be related to poorer functioning, unemployment, single relationship status, greater severity of illness, and higher antipsychotic dose. ${ }^{12}$ While the overall severity of negative symptoms is the most powerful predictor of global psychosocial functioning,,$^{19,47,49}$ correlations between specific symptoms (for example, motivational deficits) and functional outcome have been observed. ${ }^{20,50}$ It also has been reported that blunted affect and social withdrawal impact on social outcome, while lack of spontaneity affects daily functioning. ${ }^{51}$ Recent research also highlights the relevance of insight in influencing the motivational factor of self-efficacy, defined as "the confidence one has in the ability to perform a behavior or specific task," when performing social and daily living skills. ${ }^{52}$ Impaired functionality cannot be attributed 
exclusively to negative symptoms, as there may be overlap with the cognitive deficits of schizophrenia; however, this discussion is beyond the scope of the present paper. ${ }^{43}$

\section{Impact of negative symptoms on subjective variables}

Although the patient's subjective experience is difficult to evaluate in schizophrenia, ${ }^{53}$ it has been shown that negative symptoms correlate with subjective experiences of lower self-esteem, poorer satisfaction with life, and distress. These subjective variables, and self-esteem in particular, in turn impact on the functionality variables of employment, social functioning, and living situation. ${ }^{54}$ Negative symptom severity and impaired insight were significantly associated with poor work performance, and this relationship persisted over time. In contrast, positive symptom severity was not significantly associated with work performance..$^{55}$ Individuals with prominent negative symptoms demonstrated worse performance than other patients on task orientation, social skills, and personal presentation, ${ }^{56}$ and they actually experienced a greater decline in social functioning over time when employed in community settings compared with unemployment or employment in specialty mental health settings. ${ }^{57}$

\section{Impact of negative symptoms on quality of life}

Negative symptoms predict lower psychological wellbeing (such as, domains of autonomy, environmental mastery, personal growth, positive relations with others, purpose in life, self-acceptance) ${ }^{58}$ and difficulty in social competency (such as, theory of mind, attribution, empathy, self-esteem, and interpersonal self-concepts). ${ }^{59}$ The presence of negative symptoms, psychological discomfort, and resistance are powerful predictors of impaired quality of life.$^{60}$ In addition, negative symptoms correlate with caregiver burden and distress. ${ }^{61-63}$

\section{Impact of negative symptoms on remission}

The achievement of full symptomatic remission is an outcome measure in schizophrenia, and patients who achieve full remission demonstrate a level of executive function comparable to healthy controls. However, patients who achieve only positive symptomatic remission or negative symptomatic remission continue to have working memory deficits. ${ }^{64}$ Furthermore, patients with negative symptoms show global neuropsychological impairment and deficits in a number of specific domains, including social cognition, global cognition, language, and olfaction. ${ }^{1}$
Of 6,642 patients assessed in the Schizophrenia Outpatients Health Outcomes (SOHO) study, 33\% achieved long-lasting symptomatic remission, 13\% achieved longlasting functional remission, $27 \%$ achieved long-lasting adequate quality of life, and only $4 \%$ achieved recovery during the 3-year follow-up period. Greater negative symptom severity at baseline was associated with a lower likelihood of achieving recovery. ${ }^{65}$ Moreover, remission rates for negative symptoms are low, with only $6.4 \%$ of patients achieving and maintaining 6-month remission criteria. ${ }^{66}$ Thus, the goal must be effective treatment of both positive and negative symptoms together.

\section{Existing pharmacological treatment of negative symptoms}

There is no standard treatment for negative symptoms, which remain a challenge for clinicians, patients, and caregivers. The British Association for Psychopharmacology (BAP), in their 2011 guidelines for the treatment of schizophrenia, recommends addressing the secondary causes of negative symptoms first, followed by a trial of an antidepressant. ${ }^{67}$ We include here a review of the collective evidence for the use of antidepressants and antipsychotics, as these therapeutic modalities are frequently used in schizophrenia. We focus only on meta-analyses (versus individual studies), given their inclusion of greater patient numbers and the resulting increased robustness of the data.

\section{Antidepressants}

The most comprehensive meta-analysis reviewed 23 studies (eight positive and 15 negative) of antidepressants added to antipsychotics and found overall evidence of efficacy for the treatment of negative symptoms. ${ }^{68}$ Another rigorous Cochrane systematic review reached a similar conclusion, but cautioned that given only five of 139 studies met the required standards to evaluate the effect on potential confounding symptoms (for example, depressive and positive symptoms), treatment response may have been misattributed to another cause for the symptoms. This methodological concern was addressed earlier and remains problematic for many published studies in negative symptoms. ${ }^{69}$ Nonetheless, other meta-analyses of agents with antidepressant properties - alpha-2 receptor antagonists (mianserin, mirtazapine) and Ginkgo biloba (thought to increase synaptic serotonin) - also showed potential as adjunctive therapy for schizophrenia. ${ }^{68,70}$ In addition, selegiline, a monoamine oxidase (MAO) inhibitor with greater affinity for MAO-B than MAO-A, has been shown to be 
efficacious in two small trials in patients with negative symptoms. ${ }^{71,72}$

\section{Antipsychotics}

There is a lack of robust evidence for the use of antipsychotic agents as an effective approach to treating persistent negative symptoms, beyond acute inpatient hospitalization. The only exception has been amisulpride: meta-analyses of up to five double-blind, placebo-controlled studies of amisulpride in patients with predominant negative symptoms of schizophrenia found a positive correlation between the severity based on the mean SANS score at baseline and mean improvement at end point. ${ }^{73,74}$ Although these data are promising, they should be interpreted in the context of both the limitations of the trials and the possibility that the benefits of amisulpride may result from effects on secondary negative symptoms. ${ }^{75}$ Trials of antipsychotics agents for acute treatment are not appropriate for determining their effects on negative symptoms, ${ }^{74}$ but a few studies have been conducted comparing effects of monotherapy with different antipsychotics on persistent negative symptoms, with no differences among agents reported. ${ }^{76}$ Similarly, a carefully designed trial of asenapine versus olanzapine found that neither drug significantly differed from the other after 26 weeks, but long-term follow-up suggested a modest advantage for asenapine at 52 weeks. ${ }^{77,78}$ A systematic review of the efficacy of clozapine monotherapy identified six studies using the SANS negative symptom scale. Although this review favored clozapine, the findings were confounded by the difficulty of interpreting the results in the context of prominent positive symptoms because the population was largely treatment refractory and had ongoing psychotic symptoms. ${ }^{79}$

\section{Emerging pharmacological treatment of negative symptoms}

Based on the previous discussion, there is clearly a need for more efficacious agents for the treatment of negative symptoms. Table 1 summarizes published data for several investigational pharmacological agents for the treatment of negative symptoms that have shown efficacy in preliminary studies. ${ }^{17,80-115}$

\section{NMDA receptor function enhancers}

Several studies have provided preliminary evidence that increasing NMDA receptor activation through glycinesite agonists (such as, glycine, D-serine, D-cycloserine, D-alanine) improves negative symptoms in schizophrenia. ${ }^{88-92}$ Sarcosine is a naturally occurring, nonselective glycine reuptake inhibitor (GRI) used as a clinical research tool in some countries, and it has been found to improve negative symptoms in several studies. ${ }^{83-87}$ Although these results were not replicated in the largest study to date comparing glycine and D-cycloserine to placebo, ${ }^{17}$ two meta-analyses have reported a benefit with D-serine and sarcosine for the treatment of negative symptoms, ${ }^{81,82}$ and one meta-analysis has reported a benefit with glycine. ${ }^{81}$ Another therapeutic approach hypothesized to enhance NMDA receptor function involves increasing synaptic D-serine levels by diminishing its catabolism through administration of a D-amino acid oxidase (DAAO) inhibitor, such as sodium benzoate. ${ }^{116}$ Sodium benzoate was recently shown in a proof-of-concept study to improve negative symptoms when used in patients receiving a stable antipsychotic regimen..$^{93}$

A recent therapeutic approach in clinical development for negative symptoms involves targeting the glycine binding site of the NMDA receptor. ${ }^{117}$ Bitopertin, a GRI, is currently in Phase III trials. Its mechanism of action is premised on boosting the synaptic availability of glycine, a coagonist of the receptor with glutamate. ${ }^{118,119}$ In a Phase II study in patients with predominantly negative symptoms, the addition of bitopertin $10 \mathrm{mg}$ or $30 \mathrm{mg}$ once daily to a stable regimen of antipsychotic therapy significantly improved the PANSSNSFS after 8 weeks of treatment (per protocol population) with a trend toward significance in the ITT (intent-to-treat) population. ${ }^{80}$ The SearchLyte Phase III program studying adjunctive bitopertin for the treatment of symptoms of schizophrenia is composed of six trials; three in patients with predominant negative symptoms (NCT01192906, ${ }^{120}$ NCT01192880, ${ }^{121}$ NCT01192867 ${ }^{122}$ ) and three in patients with suboptimally controlled symptoms (NCT01235559, ${ }^{123}$ NCT01235585, ${ }^{124}$ NCT01235520125). The first two studies in negative symptoms did not meet their primary endpoints (reduction on the NSFS versus placebo at 6 months). ${ }^{126-128}$ Bitopertin was well tolerated, and the overall safety profile in these studies was similar to that seen in the previously reported Phase II trial. Results from other studies in the SearchLyte program are awaited.

\section{Metabotropic glutamatergic receptor activation}

Glutamatergic transmission can also be targeted by modifying activity of metabotropic glutamatergic receptors, specifically, subtype 2 (mGluR2). Agonism of this presynaptic autoreceptor decreases the amount of glutamate released in the synapse in an attempt to normalize putative excessive downstream glutamatergic tone resulting from hypofunctioning NMDA 
Table I Emerging pharmacological agents for the treatment of negative symptoms in patients with schizophrenia

\begin{tabular}{|c|c|c|c|c|}
\hline Class/agent & Mechanism of action & $\begin{array}{l}\text { Meta- } \\
\text { analysis? }\end{array}$ & $\begin{array}{l}\text { Number of studies } \\
\text { and major findings }\end{array}$ & $\begin{array}{l}\text { Number of } \\
\text { patients evaluated }\end{array}$ \\
\hline \multicolumn{5}{|c|}{ NMDA receptor function enhancers } \\
\hline \multicolumn{5}{|l|}{ Glycine-site agonists } \\
\hline \multirow[t]{4}{*}{$\begin{array}{l}\text { Glycine, D-cycloserine, } \\
\text { D-serine, D-alanine }\end{array}$} & $\begin{array}{l}\text { Increase in NMDA receptor } \\
\text { activation through glycine-site }\end{array}$ & No & $\begin{array}{l}\text { Five studies: improvement in negative } \\
\text { symptoms }^{88-92}\end{array}$ & $\mathrm{~N}=74$ \\
\hline & binding & & $\begin{array}{l}\text { CONSIST: no clinical benefit conferred } \\
\text { by glycine or D-cycloserine }{ }^{17}\end{array}$ & $\mathrm{~N}=157$ \\
\hline & & Yes & $\begin{array}{l}\text { Two meta-analyses: benefit with } \\
\text { D-serine and sarcosine for the treatment } \\
\text { of negative symptoms }{ }^{8,82}\end{array}$ & $\mathrm{~N}=|8|^{81} ; \mathrm{N}=145^{82}$ \\
\hline & & & One meta-analysis: benefit with glycine ${ }^{81}$ & $N=133$ \\
\hline $\begin{array}{l}\text { D-amino acid oxidase } \\
\text { (DAAO) inhibitors }\end{array}$ & $\begin{array}{l}\text { Increase D-serine by diminishing } \\
\text { its catabolism and increase }\end{array}$ & No & $\begin{array}{l}\text { Proof-of-concept study: improvement } \\
\text { in negative symptoms }{ }^{93}\end{array}$ & $\mathrm{~N}=53$ \\
\hline Sodium benzoate & $\begin{array}{l}\text { NMDA receptor activation } \\
\text { at the glycine-binding site }\end{array}$ & & & \\
\hline \multicolumn{5}{|c|}{ Glycine reuptake inhibitors (GRIs) } \\
\hline \multirow[t]{2}{*}{ Sarcosine } & $\begin{array}{l}\text { Naturally occurring, nonselective } \\
\text { GRI used as a clinical } \\
\text { research tool }\end{array}$ & Yes & $\begin{array}{l}\text { Two meta-analyses: benefit with } \\
\text { D-serine and sarcosine for the treatment } \\
\text { of negative symptoms }{ }^{81,82}\end{array}$ & $N=|8|^{81} ; N=145^{82}$ \\
\hline & & No & $\begin{array}{l}\text { Four studies: improvement of negative } \\
\text { symptoms with sarcosine } e^{83-87}\end{array}$ & $\begin{array}{l}N=203 \text { total across } \\
\text { four studies }\end{array}$ \\
\hline Bitopertin & $\begin{array}{l}\text { Corrects or compensates for } \\
\text { potential NMDA receptor } \\
\text { hypofunction by boosting synaptic } \\
\text { availability of glycine (NMDA } \\
\text { receptor coagonist with glutamate) }\end{array}$ & No & $\begin{array}{l}\text { Phase II study: bitopertin ( } 10 \mathrm{mg} \text { or } 30 \mathrm{mg} \\
\text { once daily) added to stable antipsychotic } \\
\text { regimen significantly improved the PANSS } \\
\text { negative symptoms factor score in patients } \\
\text { completing the trial according to protoco }{ }^{80}\end{array}$ & $\mathrm{~N}=323$ \\
\hline \multicolumn{5}{|c|}{ Metabotropic glutamatergic receptor 2 (mGluR2) } \\
\hline $\begin{array}{l}\text { Pomaglumetad methionil } \\
\text { (LY2 I 40023) }\end{array}$ & $\begin{array}{l}\text { Agonism of mGluR2/3; } \\
\text { decreases amount of glutamate } \\
\text { released in the synapse }\end{array}$ & No & $\begin{array}{l}\text { Adjunctive therapy trial: negative results; } \\
\text { development program terminated }{ }^{94}\end{array}$ & $N=167$ \\
\hline $\begin{array}{l}\text { JNJ-404II8I3/ADX- } \\
71149\end{array}$ & $\begin{array}{l}\text { Positive allosteric modulator } \\
\text { (PAM) of mGluR2 }\end{array}$ & No & $\begin{array}{l}\text { Phase lla adjunctive therapy trial: trend } \\
\text { toward separation from placebo after } \\
\text { I month at moderate doses }{ }^{95}\end{array}$ & $\mathrm{~N}=92$ \\
\hline \multicolumn{5}{|c|}{ Nicotinic acetylcholine receptors } \\
\hline EVP-6I 24 & $\begin{array}{l}\text { Alpha-7 nicotinic receptor } \\
\text { agonism }\end{array}$ & No & $\begin{array}{l}\text { Phase Ilb study: demonstrated } \\
\text { improvement of negative symptoms } \\
\text { (secondary end point) })^{96}\end{array}$ & $\mathrm{~N}=319$ \\
\hline \multirow[t]{2}{*}{ TC-5619 } & $\begin{array}{l}\text { Alpha-7 nicotinic receptor } \\
\text { agonism }\end{array}$ & No & $\begin{array}{l}\text { Phase Ilb study: negative results; } \\
\text { development program terminated }\end{array}$ & $\mathrm{N}=477$ \\
\hline & & & $\begin{array}{l}\text { Proof-of-concept study: promising results } \\
\text { on cognitive end points and negative } \\
\text { symptoms }{ }^{97}\end{array}$ & $\mathrm{~N}=185$ \\
\hline Galantamine & $\begin{array}{l}\text { Dual alpha-7 nicotinic receptor } \\
\text { PAM and cholinesterase inhibitor }\end{array}$ & No & $\begin{array}{l}\text { Small study: galantamine failed to show } \\
\text { any benefit on negative symptoms or } \\
\text { cognition but demonstrated significant } \\
\text { treatment effects for global functioning } \\
\text { and free verbal recall98 }\end{array}$ & $\mathrm{N}=43$ \\
\hline Donepezil & Cholinesterase inhibitor & Yes & $\begin{array}{l}\text { Meta-analysis of five adjunctive therapy } \\
\text { studies (two studies with galantamine; } \\
\text { three studies with donepezil): greater effect } \\
\text { on negative symptoms than cognition }{ }^{99}\end{array}$ & $\mathrm{~N}=103$ \\
\hline \multicolumn{5}{|l|}{ Psychostimulants } \\
\hline $\begin{array}{l}\text { Lisdexamfetamine } \\
\text { dimesylate }\end{array}$ & $\begin{array}{l}\text { Prodrug of dextroamphetamine } \\
\text { with CNS stimulant activity; blocks } \\
\text { the reuptake of norepinephrine } \\
\text { and dopamine into the presynaptic } \\
\text { neuron and increases their release } \\
\text { into the extraneuronal space }{ }^{100}\end{array}$ & No & $\begin{array}{l}\text { Open-label trial: potential benefit for } \\
\text { negative symptoms without aggravating } \\
\text { positive symptoms }{ }^{101,102}\end{array}$ & $N=69$ \\
\hline
\end{tabular}


Table I (Continued)

\begin{tabular}{|c|c|c|c|c|}
\hline Class/agent & Mechanism of action & $\begin{array}{l}\text { Meta- } \\
\text { analysis? }\end{array}$ & $\begin{array}{l}\text { Number of studies } \\
\text { and major findings }\end{array}$ & $\begin{array}{l}\text { Number of } \\
\text { patients evaluated }\end{array}$ \\
\hline Modafinil, armodafinil & $\begin{array}{l}\text { CNS stimulants with wake- } \\
\text { promoting actions similar to } \\
\text { amphetamine; both also bind in } \\
\text { vitro to the dopamine transporter } \\
\text { and inhibit dopamine reuptake }\end{array}$ & No & $\begin{array}{l}\text { Available study data do not conclusively } \\
\text { support use of modafinil/armodafinil } \\
\text { as add-on treatment }{ }^{102,103}\end{array}$ & $\mathrm{~N}=970$ \\
\hline \multicolumn{5}{|l|}{ Other drugs } \\
\hline $\begin{array}{l}\mathrm{N} \text {-acetyl cysteine } \\
(\mathrm{NAC})\end{array}$ & $\begin{array}{l}\text { Putative anti-inflammatory } \\
\text { agent in schizophrenia }\end{array}$ & No & $\begin{array}{l}\text { Placebo-controlled trial: NAC added } \\
\text { to routine care for } 6 \text { months improved } \\
\text { negative symptoms and akathisia }{ }^{104}\end{array}$ & $N=140$ \\
\hline Minocycline & $\begin{array}{l}\text { Putative anti-inflammatory } \\
\text { agent in schizophrenia }\end{array}$ & No & $\begin{array}{l}\text { Two placebo-controlled studies: benefit } \\
\text { in early-phase schizophrenia, especially } \\
\text { on negative symptoms, but no benefit } \\
\text { on overall psychopathology }{ }^{105,106}\end{array}$ & $\mathrm{~N}=54^{106} ; \mathrm{N}=144^{105}$ \\
\hline $\begin{array}{l}\text { Ondansetron, } \\
\text { granisetron, } \\
\text { tropisetron }\end{array}$ & $\begin{array}{l}\text { Serotonin } 5-\mathrm{HT}_{3} \text { receptor } \\
\text { antagonism; may be active in } \\
\text { schizophrenia through their } \\
\text { affinity for nicotinic and GABA } \\
\text { receptors }\end{array}$ & Yes & $\begin{array}{l}\text { Systematic review and meta-analysis: } \\
\text { greater benefit for improvement of } \\
\text { negative symptoms than positive } \\
\text { symptoms when used as add-on therapy }{ }^{107}\end{array}$ & $N=31 I$ \\
\hline Lamotrigine & $\begin{array}{l}\text { Anticonvulsant; inhibition of } \\
\text { voltage-sensitive sodium channels, } \\
\text { thereby stabilizing neuronal } \\
\text { membranes and modulating } \\
\text { presynaptic transmitter release } \\
\text { of excitatory amino acids } \\
\text { (eg, glutamate, aspartate) }\end{array}$ & Yes & $\begin{array}{l}\text { Meta-analysis of five trials: superiority in } \\
\text { overall symptom improvement and } \\
\text { improvement in positive and negative } \\
\text { symptoms }^{108}\end{array}$ & $N=|6|$ \\
\hline \multirow[t]{2}{*}{ Memantine } & NMDA receptor antagonism & Yes & $\begin{array}{l}\text { Meta-analysis: adjunctive therapy may } \\
\text { improve overall symptoms and negative } \\
\text { symptoms }^{109}\end{array}$ & $N=186$ \\
\hline & & No & $\begin{array}{l}\text { Randomized, placebo-controlled trial: } \\
\text { no benefit conferred } 110\end{array}$ & $N=138$ \\
\hline Pregnenolone & Neurosteroid & No & $\begin{array}{l}\text { Proof-of-concept trial: significantly greater } \\
\text { improvement in negative symptoms as } \\
\text { adjunctive therapy ( } 500 \mathrm{mg} / \text { day) })^{11 \prime} \\
\text { Two small studies: benefit in schizophrenia }{ }^{1 / 2}\end{array}$ & $N=21$ \\
\hline \multirow[t]{2}{*}{ Sildenafil } & $\begin{array}{l}\text { Phosphodiesterase } 5 \text { (PDE5) } \\
\text { inhibition }\end{array}$ & No & $\begin{array}{l}\text { Small study: no benefits on any symptom } \\
\text { domains }{ }^{1 / 3}\end{array}$ & $\mathrm{~N}=17$ \\
\hline & & & $\begin{array}{l}\text { Trial in patients with prominent negative } \\
\text { symptoms: significant separation from } \\
\text { placebo } 1 / 4\end{array}$ & $\mathrm{~N}=40$ \\
\hline Folic acid/vitamin $B_{12}$ & $\begin{array}{l}\text { Increase blood folate levels, } \\
\text { particularly in patients } \\
\text { homozygous for the } 484 \mathrm{~T} \\
\text { allele of FOLHI (rs202676) }\end{array}$ & No & $\begin{array}{l}\text { Randomized, placebo-controlled study: } \\
\text { effective in a subgroup of patients } \\
\text { homozygous for the } 484 \mathrm{~T} \text { allele; response } \\
\text { influenced by genetic variation in folate } \\
\text { absorption }{ }^{115}\end{array}$ & $\mathrm{~N}=140$ \\
\hline
\end{tabular}

Abbreviations: CNS, central nervous system; CONSIST, cognitive and negative symptoms in schizophrenia trial; NMDA, N-methyl-D-aspartate; PANSS, Positive and Negative Syndrome Scale; GABA, gamma-amino butyric acid.

receptors. Pomaglumetad methionil (LY2140023) is an mGluR $2 / 3$ full agonist that initially appeared promising but ultimately provided disappointing results as a monotherapy in acute psychosis and as an adjunctive agent for patients with prominent negative symptoms; as a result, the development program has been terminated ${ }^{94} \mathrm{~A}$ similar mechanism of action is being investigated with JNJ-40411813/ADX-71149, a mGluR2 positive allosteric modulator (PAM) (NCT01323205). ${ }^{129}$ The preliminary Phase IIa results suggest potential in the treatment of negative symptoms, as a trend toward separation from placebo was observed after 1 month at moderate doses of the investigational drug used as an adjunct to antipsychotics. ${ }^{95}$

\section{Nicotinic acetylcholine receptor agonists}

Agents active at alpha-7 nicotinic receptors are currently being developed as add-on therapies. It has been postulated 
that targeting cognitive functions with nicotinic receptor agonists may impact negative symptoms, as working memory is a component of reward-driven, goal-directed behavior. EVP6124 is in Phase III development for cognitive impairment associated with schizophrenia (CIAS) (NCT01714661, ${ }^{130}$ NCT01714713 ${ }^{131}$ ). In an earlier Phase IIb study, EVP-6124 met the primary end point on a cognition battery and demonstrated improvement of negative symptoms (a secondary end point). ${ }^{96}$

In an exploratory proof-of-concept trial, TC-5619 showed promising results based on cognitive end points and negative symptoms..$^{97}$ TC-5619 was recently evaluated in a Phase IIb trial (NCT01488929132), with a primary end point of improvement in negative symptoms (change from baseline after 24 weeks versus placebo). In this trial, TC-5619 did not meet the primary endpoint and did not demonstrate improvement on secondary measures of cognitive function. ${ }^{133}$ Consequently, the development program for TC-5619 as a treatment for schizophrenia has been terminated. ${ }^{133}$

A small study with galantamine, a dual PAM at the alpha-7 nicotinic receptor and a cholinesterase inhibitor, failed to show any benefit of this approach on negative symptoms or cognition but demonstrated significant treatment effects for global functioning and free verbal recall. ${ }^{98}$

A meta-analysis of adjunctive pharmacotherapies in schizophrenia found that five studies of acetylcholinesterase inhibitors (two earlier studies with galantamine and three with donepezil) demonstrated a greater effect on negative symptoms than cognition. ${ }^{99}$

\section{Psychostimulants}

The use of psychostimulants (such as methylphenidate, amphetamine, modafinil, armodafinil) in single acute experimental use and clinical trials has been reviewed recently. ${ }^{102}$ Study data do not conclusively support the use of modafinil/armodafinil as add-on treatment in schizophrenia for negative symptoms or for other attention or sleep-related symptoms. ${ }^{102,103}$ In addition, a recent open-label clinical trial with lisdexamfetamine dimesylate showed potential benefit for negative symptoms without aggravating positive symptoms. Larger placebo-controlled trials of psychostimulants are warranted to fully characterize their efficacy and safety in patients with schizophrenia. ${ }^{101,102}$

\section{Other drugs}

A systematic review of anti-inflammatory drugs for schizophrenia, such as nonsteroidal anti-inflammatory drugs (NSAIDs) and corticosteroids, and also of agents that possess additional anti-inflammatory properties, such as $\mathrm{N}$-acetyl cysteine (NAC), estrogens, melatonin, davunetide, and fatty acids, concluded that only aspirin and NAC showed significant effects. ${ }^{134}$ This analysis, however, assessed only general psychopathology and cognition. A placebo-controlled trial of NAC $1 \mathrm{~g}$ twice daily added to routine care for 6 months found improvements in negative symptoms and akathisia. ${ }^{104} \mathrm{~A}$ qualitative review of the results supported the effects of NAC on negative symptom domains such as avolition. ${ }^{135,136}$ Although minocycline did not improve overall psychopathology, two placebo-controlled studies showed a benefit in early-phase schizophrenia, especially on negative symptoms. ${ }^{105,106}$

A systematic review and meta-analysis of selective serotonin-3 $\left(5-\mathrm{HT}_{3}\right)$ receptor antagonists, including ondansetron, granisetron, and tropisetron, found that when used as add-on therapy, they conferred greater benefit for negative symptoms than positive symptoms. ${ }^{107}$ It has been hypothesized that these compounds may be active in schizophrenia based on their affinity for other receptors beyond $5-\mathrm{HT}_{3}$, such as nicotinic and GABA receptors, but it is questionable if such activity is relevant at the concentrations achieved in clinical practice.

The efficacy of lamotrigine in clozapine-resistant schizophrenia has been evaluated in a meta-analysis of five trials, with demonstration of superiority over placebo in overall symptom improvement and improvement in positive and negative symptoms. ${ }^{108}$

The data for memantine, an NMDA receptor antagonist, are mixed. A recent meta-analysis cautiously concluded that adjunctive therapy with memantine may improve overall symptoms and negative symptoms in patients with schizophrenia. However, the authors of the analysis noted that the findings from two trials in particular, in which memantine was added to clozapine or risperidone, may have influenced the results. ${ }^{109}$ Another study with a targeted patient population experiencing residual, persistent negative symptoms showed no benefit conferred by memantine. ${ }^{110}$

A proof-of-concept trial evaluating adjunctive therapy with pregnenolone (a neurosteroid) $500 \mathrm{mg}$ /day demonstrated significantly greater improvement in negative symptoms. ${ }^{111}$ Two subsequent, small studies also supported the benefit of pregnenolone in schizophrenia. ${ }^{112}$

Trials of sildenafil, a phosphodiesterase 5 (PDE5) inhibitor, have yielded conflicting results. The first placebocontrolled augmentation study failed to show any benefits of sildenafil on any symptom domains of schizophrenia. ${ }^{113}$ However, a subsequent trial in patients with prominent negative symptoms demonstrated a significant separation from placebo for sildenafil. ${ }^{114}$ 
Another investigational approach, inspired by the correlation of low serum folate levels with the manifestation of negative symptoms, evaluated the efficacy of adjunctive daily oral folic acid plus vitamin B12 or placebo. The overall results were negative; however, for a subgroup of patients, the treatment was effective, and response was influenced by genetic variation in folate absorption. ${ }^{115}$

\section{Future research}

The unmet need in the treatment of negative symptoms of schizophrenia is unequivocal. The neurobiological mechanisms underpinning negative symptoms are complex and remain to be clearly elucidated. Despite the considerable investment of time and money, progress in developing agents with robust efficacy for negative symptoms has been limited. The most recent findings from studies with TC-5619 and bitopertin clearly highlight this difficulty. Furthermore, even if effective agents are identified, their place in therapy (such as single primary agent or adjunctive agent) and timing/scheduling in individual patients add multiple layers of complexity. ${ }^{117}$

\section{Conclusion}

Negative symptoms represent a core symptom domain in schizophrenia. Despite progress in pharmacological treatments for the positive symptoms of schizophrenia, no standard treatment exists for negative symptoms. This review attempts to summarize the evolving landscape of emerging treatments in development and new findings from available drugs that could benefit patients with prominent negative symptoms. Barriers to studying negative symptoms and interpreting results are discussed, including the difficulties in designing clinical trials. A review of nonpharmacological interventions was out of scope in this paper, but such interventions do merit a separate assessment, as these modalities are likely to further improve outcomes of any pharmacological treatment. Additionally, assessing and treating all aspects of schizophrenia early with an empirical and individualized approach, taking into account psychosocial and environmental factors, is clearly important given the limitations of the current pharmacotherapeutic armamentarium. Novel compounds in advanced clinical development focus on modulation of glutamatergic and cholinergic systems via the targeting of NMDA, mGluR2, and nicotinic receptors, respectively. Other therapeutic options with varying degrees of supportive evidence are also outlined. There is a need for better pharmacological agents for managing the negative symptoms of schizophrenia, which have been shown to contribute significantly to poor functioning and detrimentally impact clinical outcomes.

\section{Acknowledgments}

Editorial assistance was provided by ApotheCom and was financially supported by F Hoffmann-La Roche Ltd.

\section{Disclosure}

Pierre Chue has received research grants and honoraria from Janssen, Pfizer, Eli Lilly, Astra Zeneca, GlaxoSmithKline, Lundbeck, Bristol-Myers Squibb, F Hoffmann-La Roche Ltd, Sunovion, Mylan, Otsuka, and Novartis. Justine Lalonde is an employee of F Hoffmann-La Roche Ltd.

\section{References}

1. Kirkpatrick B, Galderisi S. Deficit schizophrenia: an update. World Psychiatry. 2008;7(3):143-147.

2. Andreasen NC. Negative symptoms in schizophrenia. Definition and reliability. Arch Gen Psychiatry. 1982;39(7):784-788.

3. Blanchard JJ, Kring AM, Horan WP, Gur R. Toward the next generation of negative symptom assessments: the collaboration to advance negative symptom assessment in schizophrenia. Schizophr Bull. 2011;37(2): 291-299.

4. Foussias G, Remington G. Negative symptoms in schizophrenia: avolition and Occam's razor. Schizophr Bull. 2010;36(2): 359-369.

5. Choi J, Medalia A. Intrinsic motivation and learning in a schizophrenia spectrum sample. Schizophr Res. 2010;118(1-3):12-19.

6. Tamminga CA, Buchanan RW, Gold JM. The role of negative symptoms and cognitive dysfunction in schizophrenia outcome. Int Clin Psychopharmacol. 1998;13(Suppl 3):S21-S26.

7. Peralta V, Cuesta MJ, Martinez-Larrea A, Serrano JF. Differentiating primary from secondary negative symptoms in schizophrenia: a study of neuroleptic-naive patients before and after treatment. Am J Psychiatry. 2000;157(9):1461-1466.

8. Hovington CL, Bodnar M, Joober R, Malla AK, Lepage M. Identifying persistent negative symptoms in first episode psychosis. $B M C$ Psychiatry. 2012;12:224.

9. Chang WC, Hui CL, Tang JY, et al. Persistent negative symptoms in first-episode schizophrenia: a prospective three-year follow-up study. Schizophr Res. 2011;133(1-3):22-28.

10. Mäkinen J, Miettunen J, Jääskeläinen E, Veijola J, Isohanni M, Koponen H. Negative symptoms and their predictors in schizophrenia within the Northern Finland 1966 Birth Cohort. Psychiatr Res. 2010;178(1): 121-125.

11. Galderisi S, Bucci P, Üçok A, Peuskens J. No gender differences in social outcome in patients suffering from schizophrenia. Eur Psychiatry. 2012;27(6):406-408.

12. Bobes J, Arango C, Garcia-Garcia M, Rejas J; CLAMORS Study Collaborative Group. Prevalence of negative symptoms in outpatients with schizophrenia spectrum disorders treated with antipsychotics in routine clinical practice: findings from the CLAMORS study. J Clin Psychiatry. 2010;71(3):280-286.

13. Tek C, Kirkpatrick B, Buchanan RW. A five-year followup study of deficit and nondeficit schizophrenia. Schizophr Res. 2001;49(3):253-260.

14. Lehman AF, Lieberman JA, Dixon LB, et al; for the American Psychiatric Association, Steering Committee on Practice Guidelines. Practice guideline for the treatment of patients with schizophrenia, second edition. Am J Psychiatry. 2004;161(suppl 2):1-56.

15. Flaum M, Andreasen N. The reliability of distinguishing primary versus secondary negative symptoms. Compr Psychiatry. 1995;36(6): 421-427.

16. Peralta V, Cuesta MJ. Negative parkinsonian, depressive and catatonic symptoms in schizophrenia: a conflict of paradigms revisited. Schizophr Res. 1999;40(3):245-253. 
17. Buchanan RW, Javitt DC, Marder SR, et al. The cognitive and negative symptoms in schizophrenia trial (CONSIST): The efficacy of glutamatergic agents for negative symptoms and cognitive impairments. Am J Psychiatry. 2007;164(10):1593-1602.

18. Mäkinen J, Miettunen J, Isohanni M, Koponen H. Negative symptoms in schizophrenia: a review. Nord J Psychiatry. 2008;62(5):334-341.

19. Galderisi S, Bucci P, Mucci A, et al. Categorical and dimensional approaches to negative symptoms of schizophrenia: focus on long-term stability and functional outcome. Schizophr Res. 2013;147(1):157-162.

20. Fervaha G, Foussias G, Agid O, Remington G. Amotivation and functional outcomes in early schizophrenia. Psychiatry Res. 2013;210(2):665-668.

21. Foussias G, et al. Negative symptoms across the schizophrenia spectrum: Phenomenological and neurobiological perspectives. In: Ritsner MS, editor. Handbook of Schizophrenia Spectrum Disorders, Volume II: Phenotypic and Endophenotypic Presentations. New York, NY: Springer; 2011:1-32.

22. Dowd EC, Barch DM. Anhedonia and emotional experience in schizophrenia: neural and behavioral indicators. Biol Psychiatry. 2010;67(10):902-911.

23. Gold JM, Waltz JA, Prentice KJ, Morris SE, Heerey EA. Reward processing in schizophrenia: a deficit in the representation of value. Schizophr Bull. 2008;34(5):835-847.

24. Goghari VM, Sponheim SR, MacDonald AW 3rd. The functional neuroanatomy of symptom dimensions in schizophrenia: a qualitative and quantitative review of a persistent question. Neurosci Biobehav Rev. 2010;34(3):468-486.

25. Harvey PO, Armony J, Malla A, Lepage M. Functional neural substrates of self-reported physical anhedonia in non-clinical individuals and in patients with schizophrenia. J Psychiatr Res. 2010;44(11):707-716.

26. Juckel G, Schlagenhauf F, Koslowski M, et al. Dysfunction of ventral striatal reward prediction in schizophrenia. Neuroimage. 2006;29(2): 409-416.

27. Lewis DA, Moghaddam B. Cognitive dysfunction in schizophrenia: convergence of gamma-aminobutyric acid and glutamate alterations. Arch Neurol. 2006;63(10):1372-1376.

28. Murase S, Mathé JM, Grenhoff J, Svensson TH. Effects of dizocilpine (MK-801) on rat midbrain dopamine cell activity: differential actions on firing pattern related to anatomical localization. $J$ Neural Transm Gen Sect. 1993;91(1):13-25.

29. Witkin JM. Blockade of the locomotor stimulant effects of cocaine and methamphetamine by glutamate antagonists. Life Sci. 1993;53(24):PL405-PL410.

30. Takahata R, Moghaddam B. Glutamatergic regulation of basal and stimulus-activated dopamine release in the prefrontal cortex. J Neurochem. 1998;71(4):1443-1449.

31. Kiss T, Hoffmann WE, Scott L, et al. Role of thalamic projection in NMDA receptor-induced disruption of cortical slow oscillation and short-term plasticity. Front Psychiatry. 2011;2:14.

32. Tomitaka S, Tomitaka M, Tolliver BK, Sharp FR. Bilateral blockade of NMDA receptors in anterior thalamus by dizocilpine (MK-801) injures pyramidal neurons in rat retrosplenial cortex. Eur J Neurosci. 2000;12(4):1420-1430.

33. Lorrain DS, Baccei CS, Bristow LJ, Anderson JJ, Varney MA. Effects of ketamine and N-methyl-D-aspartate on glutamate and dopamine release in the rat prefrontal cortex: modulation by a group II selective metabotropic glutamate receptor agonist LY379268. Neuroscience. 2003;117(3):697-706.

34. Kirkpatrick B, Fenton WS, Carpenter WT Jr, Marder SR. The NIMHMATRICS consensus statement on negative symptoms. Schizophr Bull. 2006;32(2):214-219.

35. Kring AM, Gur RE, Blanchard JJ, Horan WP, Reise SP. The Clinical Assessment Interview for Negative Symptoms (CAINS): final development and validation. Am J Psychiatry. 2013;170(2):165-172.

36. Strauss GP, Keller WR, Buchanan RW, et al. Next-generation negative symptom assessment for clinical trials: validation of the Brief Negative Symptom Scale. Schizophr Res. 2012a;142(1-3):88-92.
37. Marder SR, Davis JM, Chouinard G. The effects of risperidone on the five dimensions of schizophrenia derived by factor analysis: combined results of the North American trials. J Clin Psychiatry. 1997;58(12):538-546.

38. Levine SZ, Rabinowitz J. Revisiting the 5 dimensions of the Positive and Negative Syndrome Scale. J Clin Psychopharmacol. 2007;27(5): 431-436.

39. Marder SR, Kirkpatrick B. Defining and measuring negative symptoms of schizophrenia in clinical trials. Eur Neuropsychopharmacol. 2013; Epub 11 November (DOI: 10.1016/j.euroneuro.2013.10.016).

40. Marder SR, Daniel DG, Alphs L, Awad G. Methodological issues in negative symptom trials. Schizophr Bull. 2011;37(2):250-254.

41. Marder SR, Alphs L, Anghelescu I, et al. Issues and perspectives in designing clinical trials for negative symptoms in schizophrenia. Schizophr Res. 2013;150(2-3):328-333.

42. Hunter R, Barry S. Negative symptoms and psychosocial functioning in schizophrenia: Neglected but important targets for treatment. Eur Psychiatry. 2012;27(6):432-436.

43. Llorca PM, Blanc O, Samalin L, Bosia M, Cavallaro R; EGOFORS Initiative. Factors involved in the level of functioning of patients with schizophrenia according to latent variable modeling. Eur Psychiatry. 2012;27(6):396-400.

44. Green MF. What are the functional consequences of neurocognitive deficits in schizophrenia? Am J Psychiatry. 1996;153(3):321-330.

45. HoferA, Baumgartner S, Edlinger M, et al. Patient outcomes in schizophrenia I: correlates with sociodemographic variables, psychopathology, and side effects. Eur Psychiatry. 2005;20(5-6):386-394.

46. Rosenheck RA, Leslie DL, Sindelar J, et al. Cost-effectiveness of second-generation antipsychotics and perphenazine in a randomized trial of treatment for chronic schizophrenia. Am J Psychiatry. 2006;163(12):2080-2089.

47. Rabinowitz J, Levine SZ, Garibaldi G, Bugarski-Kirola D, Berardo CG, Kapur S. Negative symptoms have greater impact on functioning than positive symptoms in schizophrenia: analysis of CATIE data. Schizophr Res. 2012;137(1-3):147-150.

48. Rabinowitz J, Berardo CG, Bugarski-Kirola D, Marder S. Association of prominent positive and prominent negative symptoms and functional health, well-being, healthcare-related quality of life and family burden: A CATIE analysis. Schizophr Res. 2013;150(2-3):339-342.

49. Milev P, Ho BC, Arndt S, Andreasen NC. Predictive values of neurocognition and negative symptoms on functional outcome in schizophrenia: a longitudinal first-episode study with 7-year follow-up. Am J Psychiatry. 2005;162(3):495-506.

50. Foussias G, Mann S, Zakzanis KK, van Reekum R, Agid O, Remington G. Prediction of longitudinal functional outcomes in schizophrenia: the impact of baseline motivational deficits. Schizophr Res. 2011;132(1):24-27.

51. Leifker FR, Bowie CR, Harvey PD. Determinants of everyday outcomes in schizophrenia: the influences of cognitive impairment, functional capacity, and symptoms. Schizophr Res. 2009;115(1):82-87.

52. Kurtz MM, Olfson RH, Rose J. Self-efficacy and functional status in schizophrenia: relationship to insight, cognition and negative symptoms. Schizophr Res. 2013;145(1-3):69-74.

53. Bouricius JK. Negative symptoms and emotions in schizophrenia. Schizophr Bull. 1989;15(2):201-208.

54. Brekke JS, Levin S, Wolkon GH, Sobel E, Slade E. Psychosocial functioning and subjective experience in schizophrenia. Schizophr Bull. 1993;19(3):599-608.

55. Erickson M, Jaafari N, Lysaker P. Insight and negative symptoms as predictors of functioning in a work setting in patients with schizophrenia. Psychiatry Res. 2011;189(2):161-165.

56. Lysaker P, Bell M. Negative symptoms and vocational impairment in schizophrenia: repeated measurements of work performance over six months. Acta Psychiatr Scand. 1995;91(3):205-208.

57. Weinberg D, Shahar G, Davidson L, McGlashan TH, Fennig S. Longitudinal associations between negative symptoms and social functioning in schizophrenia: the moderating role of employment status and setting. Psychiatry. 2009;72(4):370-381. 
58. Strauss GP, Sandt AR, Catalano LT, Allen DN. Negative symptoms and depression predict lower psychological well-being in individuals with schizophrenia. Compr Psychiatry. 2012b;53(8):1137-1144.

59. Lincoln TM, Mehl S, Kesting ML, Rief W. Negative symptoms and social cognition: identifying targets for psychological interventions. Schizophr Bull. 2011;37(suppl 2):S23-S32.

60. Fujimaki K, Morinobu S, Yamashita H, Takahashi T, Yamawaki S Predictors of quality of life in inpatients with schizophrenia. Psychiatry Res. 2012;197(3):199-205.

61. Stahl SM, Buckley PF. Negative symptoms of schizophrenia: a problem that will not go away. Acta Psychiatrica Scand. 2007;115(1):4-11.

62. Dyck DG, Short R, Vitaliano PP. Predictors of burden and infectious illness in schizophrenia caregivers. Psychosom Med. 1999;61(4):411-419.

63. Provencher HL, Mueser KT. Positive and negative symptom behaviors and caregiver burden in the relatives of persons with schizophrenia. Schizophr Res. 1997;26(1):71-80.

64. Braw Y, Benozio A, Levkovitz Y. Executive functioning during full and partial remission (positive and negative symptomatic remission) of schizophrenia. Schizophr Res. 2012;142(1-3):122-128.

65. Novick D, Haro JM, Suarez D, Vieta E, Naber D. Recovery in the outpatient setting: 36-month results from the Schizophrenia Outpatients Health Outcomes (SOHO) study. Schizophr Res. 2009; 108(1-3):223-230.

66. Levine SZ, Leucht S. Attaining and sustaining remission of predominant negative symptoms. Schizophr Res. 2013;143(1):60-64.

67. Barnes TR; Schizophrenia Consensus Group of British Association for Psychopharmacology. Evidence-based guidelines for the pharmacological treatment of schizophrenia: recommendations from the British Association for Psychopharmacology. J Psychopharmacol. 2011;25(5):567-620.

68. Singh SP, Singh V, Kar N, Chan K. Efficacy of antidepressants in treating the negative symptoms of chronic schizophrenia: meta-analysis. Br J Psychiatry. 2010;197(3):174-179.

69. Rummel C, Kissling W, Leucht S. Antidepressants for the negative symptoms of schizophrenia. Cochrane Database Syst Rev. 2006;(3):CD005581.

70. Hecht EM, Landy DC. Alpha-2 receptor antagonist add-on therapy in the treatment of schizophrenia; a meta-analysis. Schizophr Res. 2012;134(2-3):202-206.

71. Bodkin JA, Siris SG, Bermanzohn PC, Hennen J, Cole JO. Doubleblind, placebo-controlled, multicenter trial of selegiline augmentation of antipsychotic medication to treat negative symptoms in outpatients with schizophrenia. Am J Psychiatry. 2005;162(2):388-390.

72. Amiri A, Noorbala AA, Nejatisafa AA, et al. Efficacy of selegiline add on therapy to risperidone in the treatment of the negative symptoms of schizophrenia: a double-blind randomized placebo-controlled study. Hum Psychopharmacol. 2008;23(2):79-86.

73. Storosum JG, Elferink AJ, van Zwieten BJ, van Strik R, Hoogendijk WJ, Broekmans AW. Amisulpride: is there a treatment for negative symptoms in schizophrenia patients? Schizophr Bull. 2002;28(2): 193-201.

74. Leucht S, Kissling W, Davis JM. Second-generation antipsychotics for schizophrenia: can we resolve the conflict? Psychol Med. 2009;39: 1591-1602.

75. Arango C, Garibaldi G, Marder SR. Pharmacological approaches to treating negative symptoms: A review of clinical trials. Schizophr Res. 2013;150(2-3):346-352.

76. National Institute for Health and Clinical Excellence (NICE), National Collaborating Centre for Mental Health. The NICE Guideline on Core Interventions in the Treatment and Management of Schizophrenia in Adults in Primary and Secondary Care (Updated Edition). National Clinical Guideline Number 82. Leicester, UK: The British Psychological Society and The Royal College of Psychiatrists; 2010.

77. Buchanan RW, Panagides J, Zhao J, et al. Asenapine versus olanzapine in people with persistent negative symptoms of schizophrenia. J Clin Psychopharmacol. 2012;32(1):36-45.
78. Potkin SG, Phiri P, Szegedi A, Zhao J, Alphs L, Cazorla P. Long-term effects of asenapine or olanzapine in patients with persistent negative symptoms of schizophrenia: A pooled analysis. Schizophr Res. 2013;150(2-3):442-449.

79. Essali A, Al-Haj Haasan N, Li C, Rathbone J. Clozapine versus typical neuroleptic medication for schizophrenia. Cochrane Database Syst Rev. 2009;(1):CD000059.

80. Umbricht D, Alberati D, Martin-Facklam M, et al. Effect of bitopertin, a glycine reuptake inhibitor, on negative symptoms of schizophrenia: a randomized, double-blind, proof-of-concept study. JAMA Psychiatry. 2014; Epub 2 April (DOI: 10.1001/jamapsychiatry.2014.163).

81. Tsai GE, Lin PY. Strategies to enhance N-methyl-D-aspartate receptormediated neurotransmission in schizophrenia, a critical review and meta-analysis. Curr Pharm Des. 2010;16(5):522-537.

82. Singh SP, Singh V. Meta-analysis of the efficacy of adjunctive NMDA receptor modulators in chronic schizophrenia. CNS Drugs. 2011;25(10): $859-885$.

83. Tsai G, Lane HY, Yang P, Chong MY, Lange N. Glycine transporter I inhibitor, N-methylglycine (sarcosine), added to antipsychotics for the treatment of schizophrenia. Biol Psychiatry. 2004;55(5):452-456.

84. Lane HY, Chang YC, Liu YC, Chiu CC, Tsai GE. Sarcosine or D-serine add-on treatment for acute exacerbation of schizophrenia: a randomized, double-blind, placebo-controlled study. Arch Gen Psychiatry. 2005;62(11):1196-1204.

85. Lane HY, Huang CL, Wu PL, et al. Glycine transporter 1 inhibitor, $\mathrm{N}$-methylglycine (sarcosine), added to clozapine for the treatment of schizophrenia. Biol Psychiatry. 2006;60(6):645-649.

86. Lane HY, Liu YC, Huang CL, et al. Sarcosine (N-methylglycine) treatment for acute schizophrenia: a randomized, double-blind study. Biol Psychiatry. 2008;63(1):9-12.

87. Lane HY, Lin CH, Huang YJ, et al. A randomized, double-blind, placebocontrolled comparison study of sarcosine ( $\mathrm{N}$-methylglycine) and D-serine add-on treatment for schizophrenia. Int $J$ Neuropsychopharmacol. 2010;13(4):451-460.

88. Evins AE, Amico E, Posever TA, Toker R, Goff DC. D-Cycloserine added to risperidone in patients with primary negative symptoms of schizophrenia. Schizophr Res. 2002;56(1-2):19-23.

89. Heresco-Levy U, Javitt DC. Comparative effects of glycine and D-cycloserine on persistent negative symptoms in schizophrenia: a retrospective analysis. Schizophr Res. 2004;66:89-96.

90. Heresco-Levy U, Javitt DC, Ermilov M, et al. Double-blind, placebocontrolled, crossover trial of glycine adjuvant therapy for treatmentresistant schizophrenia. Br J Psychiatry. 1996;169:610-617.

91. Heresco-Levy U, Javitt DC, Ermilov M, et al. Efficacy of highdose glycine in the treatment of enduring negative symptoms of schizophrenia. Arch Gen Psychiatry. 1999;56(1):29-36.

92. Javitt DC, Zylberman I, Zukin SR, Heresco-Levy U, Lindenmayer JP. Amelioration of negative symptoms in schizophrenia by glycine. Am J Psychiatry. 1994;151(8):1234-1236.

93. Lane HY, Lin CH, Green MF, et al. Add-on treatment of benzoate for schizophrenia: a randomized, double-blind, placebo-controlled trial of d-amino acid oxidase inhibitor. JAMA Psychiatry. 2013;70(12): $1267-1275$

94. Stauffer VL, Millen BA, Andersen S, et al. Pomaglumetad methionil: No significant difference as an adjunctive treatment for patients with prominent negative symptoms of schizophrenia compared to placebo. Schizophr Res. 2013;150(2-3):434-441.

95. De Boer P, Sinha V, Hoeben E, et al. Characterization of the clinical effect of a positive allosteric modulator of the metabotropic glutamate receptor-2 [poster \#998]. Presented at 68th Annual Scientific Convention of Society of Biological Psychiatry; May 16-18, 2013; San Francisco, CA.

96. EnVivo Pharmaceuticals. EnVivo Pharmaceuticals presents positive comprehensive phase $2 \mathrm{~b}$ study results in schizophrenia at American College of Neuropsychopharmacology annual meeting [press release]; December 5, 2011. Available from: http://www.envivopharma.com/ news-item.php?id=35. Accessed March 5, 2014. 
97. Lieberman JA, Dunbar G, Segreti AC, et al. A randomized exploratory trial of an alpha-7 nicotinic receptor agonist (TC-5619) for cognitive enhancement in schizophrenia. Neuropsychopharmacology. 2013;38(6):968-975.

98. Deutsch SI, SchwartzBL, SchoolerNR, Brown CH, Rosse RB, Rosse SM. Targeting alpha-7 nicotinic neurotransmission in schizophrenia: a novel agonist strategy. Schizophr Res. 2013;148(1-3):138-144.

99. Choi KH, Wykes T, Kurtz MM. Adjunctive pharmacotherapy for cognitive deficits in schizophrenia: meta-analytical investigation of efficacy. Br J Psychiatry. 2013;203:172-178.

100. Vyvanse (lisdexamfetamine dimesylate) [package insert]. Wayne, PA: Shire US Inc.; 2013.

101. Lasser RA, Dirks B, Nasrallah H, et al. Adjunctive lisdexamfetamine dimesylate therapy in adult outpatients with predominant negative symptoms of schizophrenia: open-label and randomized-withdrawal phases. Neuropsychopharmacology. 2013;38(11):2140-2149.

102. Lindenmayer JP, Nasrallah H, Pucci M, James S, Citrome L. A systematic review of psychostimulant treatment of negative symptoms of schizophrenia: challenges and therapeutic opportunities. Schizophr Res. 2013;147(2-3):241-252.

103. Wittkampf LC, Arends J, Timmerman L, Lancel M. A review of modafinil and armodafinil as add-on therapy in antipsychotic-treated patients with schizophrenia. Ther Adv Psychopharmacol. 2012;2(3): 115-125

104. Berk M, Copolov D, Dean O, et al. N-acetyl cysteine as a glutathione precursor for schizophrenia - a double-blind, randomized, placebocontrolled trial. Biol Psychiatry. 2008;64(5):361-368.

105. Chaudhry IB, Hallak J, Husain N, et al. Minocycline benefits negative symptoms in early schizophrenia: a randomised double-blind placebo-controlled clinical trial in patients on standard treatment. J Psychopharmacol. 2012;26(9):1185-1193.

106. Levkovitz Y, Mendlovich S, Riwkes S, et al. A double-blind, randomized study of minocycline for the treatment of negative and cognitive symptoms in early-phase schizophrenia. J Clin Psychiatry. 2010;71(2):138-149.

107. Kishi T, Mukai T, Matsuda Y, Iwata N. Selective serotonin 3 receptor antagonist treatment for schizophrenia: Meta-analysis and systematic review. Neuromolecular Med. 2014;16(1):61-69.

108. Tiihonen J, Wahlbeck K, Kiviniemi V. The efficacy of lamotrigine in clozapine-resistant schizophrenia: a systematic review and metaanalysis. Schizophr Res. 2009;109(1-3):10-14.

109. Kishi T, Iwata N. NMDA receptor antagonists interventions in schizophrenia: Meta-analysis of randomized, placebo-controlled trials. J Psychiatr Res. 2013;47(9):1143-1149.

110. Lieberman JA, Papadakis K, Csernansky J, et al; for the MEMMD-29 Study Group. A randomized, placebo-controlled study of memantine as adjunctive treatment in patients with schizophrenia. Neuropsychopharmacology. 2009;34(5):1322-1329.

111. Marx CE, Keefe RS, Buchanan RW, et al. Proof-of-concept trial with the neurosteroid pregnenolone targeting cognitive and negative symptoms in schizophrenia. Neuropsychopharmacology. 2009;34(8): 1885-1903.

112. Marx CE, Bradford DW, Hamer RM, et al. Pregnenolone as a novel therapeutic candidate in schizophrenia: emerging preclinical and clinical evidence. Neuroscience. 2011;191:78-90.

113. Goff DC, Cather C, Freudenreich O, et al. A placebo-controlled study of sildenafil effects on cognition in schizophrenia. Psychopharmacology. 2009;202(1-3):411-417.

114. Akhondzadeh S, Ghayyoumi R, Rezaei F, et al. Sildenafil adjunctive therapy to risperidone in the treatment of the negative symptoms of schizophrenia: a double-blind randomized placebo-controlled trial. Psychopharmacology. 2011;213(4):809-815.

115. Roffman JL, Lamberti JS, Achtyes E, et al. Randomized multicenter investigation of folate plus vitamin $\mathrm{B}_{12}$ supplementation in schizophrenia. JAMA Psychiatry. 2013;70(5):481-489.

116. Nunes EA, MacKenzie EM, Rossolatos D, Perez-Parada J, Baker GB, Dursun SM. D-serine and schizophrenia: an update. Expert Rev Neurother. 2012;12(7):801-812
117. Chue P, Baker GB. Glycine reuptake inhibition: a promising therapeutic strategy in the treatment of schizophrenia? Future Med Chem. 2013;5(13):1475-1477.

118. Chue P. Glycine reuptake inhibition as a new therapeutic approach in schizophrenia: focus on the glycine transporter 1 (GlyT1). Curr Pharm Des. 2013;19(7):1311-1320.

119. Kantrowitz JT, Javitt DC. N-methyl-d-aspartate (NMDA) receptor dysfunction or dysregulation: the final common pathway on the road to schizophrenia? Brain Res Bull. 2010;83:108-121.

120. Hoffmann-La Roche. A Study of RO4917838 (Bitopertin) in Patients With Persistent, Predominant Negative Symptoms of Schizophrenia (WN25309). In: ClinicalTrials.gov [website on the Internet]. Bethesda, MD: US National Library of Medicine; 2010 [updated January 6, 2014]. Available from http://clinicaltrials.gov/ct2/show/NCT01192906. NLM identifier: NCT01192906. Accessed March 10, 2014.

121. Hoffmann-La Roche. A Study of RO4917838 (Bitopertin) in Patients With Persistent, Predominant Negative Symptoms of Schizophrenia (WN25308). In: ClinicalTrials.gov [website on the Internet]. Bethesda, MD: US National Library of Medicine; 2010 [updated March 3, 2014]. Available from http://clinicaltrials.gov/ct2/show/NCT01192880?term= NCT01192880\&rank=1. NLM identifier: NCT01192880. Accessed March 10, 2014

122. Hoffmann-La Roche. A Study of RO4917838 in Patients With Persistent, Predominant Negative Symptoms of Schizophrenia (NN25310). In: ClinicalTrials.gov [website on the Internet]. Bethesda, MD: US National Library of Medicine; 2010 [updated January 13, 2014]. Available from http://clinicaltrials.gov/ct2/show/NCT01192867?term= NCT01192867\&rank=1. NLM identifier: NCT01192867. Accessed March 10, 2104.

123. Hoffmann-La Roche. A Study of RO4917838 (Bitopertin) in Patients With Sub-optimally Controlled Symptoms of Schizophrenia (WN25305). In: ClinicalTrials.gov [website on the Internet]. Bethesda, MD: US National Library of Medicine; 2010 [updated March 3, 2014]. Available from http://clinicaltrials.gov/ct2/show/NCT01235559?term= nCT01235559\&rank=1. NLM identifier: NCT01235559. Accessed March 3, 2014.

124. Hoffmann-La Roche. A Study of RO4917838 (Bitopertin) in Patients With Sub-optimally Controlled Symptoms of Schizophrenia (WN25306). In: ClinicalTrials.gov [website on the Internet]. Bethesda, MD: US National Library of Medicine; 2010 [updated March 3, 2014]. Available from http://clinicaltrials.gov/ct2/show/NCT01235585?term= NCT01235585\&rank=1. NLM identifier: NCT01235585. Accessed March 10, 2014

125. Hoffmann-La Roche. A Study of RO4917838 in Patients With Suboptimally Controlled Symptoms of Schizophrenia (NN25307). In: ClinicalTrials.gov [website on the Internet]. Bethesda, MD: US National Library of Medicine; 2010 [updated January 20, 2014]. Available from http://clinicaltrials.gov/ct2/show/NCT01235520?term= NCT01235520\&rank=1. NLM identifier: NCT01235520. Accessed March 10, 2014.

126. Arango C, Nasrallah H, Lawrie S, et al. Efficacy and safety of adjunctive bitopertin ( 5 and $10 \mathrm{mg}$ ) versus placebo in subjects with persistent predominant negative symptoms of schizophrenia treated with antipsychotics - Results from the Phase III DayLyte study. Poster presented at: 4th Biennial Schizophrenia International Research Society Conference, April 5-9, 2014, Florence, Italy.

127. Blaettler T, Bugarski-Kirola D, Fleischhacker W, et al. Efficacy and safety of adjunctive bitopertin (10 and $20 \mathrm{mg}$ ) versus placebo in subjects with persistent predominant negative symptoms of schizophrenia treated with antipsychotics - Results from the Phase III FlashLyte study. Poster presented at: 4th Biennial Schizophrenia International Research Society Conference, April 5-9, 2014, Florence, Italy.

128. Bugarski-Kirola D, Arango C, Fleischhacker W, et al. Efficacy and Safety of Adjunctive Bitopertin versus Placebo in Subjects with Persistent Predominant Negative Symptoms of Schizophrenia Treated with Antipsychotics - Update from the SearchLyte Programme. Schizophr Res. 2014;153(Suppl 1):S29. 
129. Janssen Research \& Development, LLC. Investigation of the Safety, Tolerability and Potential Therapeutic Effects of JNJ-40411813 in Patients With Schizophrenia. In: ClinicalTrials.gov [website on the Internet]. Bethesda, MD: US National Library of Medicine; 2011 [updated December 24, 2013]. Available from http://clinicaltrials. gov/show/NCT01323205. NLM identifier: NCT01323205. Accessed March 10, 2014.

130. EnVivo Pharmaceuticals, Inc. Study of EVP-6124 (Alpha-7 nAChR) as an Adjunctive Pro-Cognitive Treatment in Schizophrenia Subjects on Chronic Stable Atypical Antipsychotic Therapy. In: ClinicalTrials. gov [website on the Internet]. Bethesda, MD: US National Library of Medicine; 2012 [updated February 12, 2014]. Available from http:// clinicaltrials.gov/ct2/show/NCT01714661?term=NCT01714661\& rank=1. NLM identifier: NCT01714661. Accessed March 10, 2014.

131. EnVivo Pharmaceuticals, Inc. A 26-Week Extension Study of EVP6124 (Alpha-7 nAChR) as an Adjunctive Pro-Cognitive Treatment in Schizophrenia Subjects on Chronic Stable Atypical Antipsychotic Therapy. In: ClinicalTrials.gov [website on the Internet]. Bethesda, MD: US National Library of Medicine; 2012 [updated February 12, 2014]. Available from http://clinicaltrials.gov/ct2/show/NCT017147 13?term=NCT01714713\&rank=1. NLM identifier: NCT01714713. Accessed March 10, 2014.
132. Targacept Inc. Efficacy, Safety, and Tolerability of TC-5619 as Augmentation Therapy to Improve Negative Symptoms and Cognition in Outpatients With Schizophrenia. In: ClinicalTrials.gov [website on the Internet]. Bethesda, MD: US National Library of Medicine; 2011 [updated December 6, 2013]. Available from http://clinicaltrials.gov/ ct2/show/NCT01488929?term=NCT01488929\&rank=1. NLM identifier: NCT01488929. Accessed March 10, 2014.

133. Targacept. Targacept announces negative top-line results from phase $2 \mathrm{~b}$ clinical trial of TC-5619 in schizophrenia [press release]; December 16 2013. Available from: http://www.targacept.com/newsroom/index.cfm. Accessed March 5, 2014.

134. Sommer IE, van Westrhenen R, Begemann MJ, de Witte LD, Leucht S, Kahn RS. Efficacy of anti-inflammatory agents to improve symptoms in patients with schizophrenia: An update. Schizophr Bull 2014;40(1):181-191.

135. Berk M, Munib A, Dean O, et al. Qualitative methods in early-phase drug trials: broadening the scope of data and methods from and RCT of N-acetylcysteine in schizophrenia. J Clin Psychiatry. 2011;72(7): 909-913.

136. Dean O, Giorlando F, Berk M. N-acetylcysteine in psychiatry: current therapeutic evidence and potential mechanisms of action. JPsychiatry Neurosci. 2011;36(2):78-86.
Neuropsychiatric Disease and Treatment

\section{Publish your work in this journal}

Neuropsychiatric Disease and Treatment is an international, peerreviewed journal of clinical therapeutics and pharmacology focusing on concise rapid reporting of clinical or pre-clinical studies on a range of neuropsychiatric and neurological disorders. This journa is indexed on PubMed Central, the 'PsycINFO' database and CAS.

\section{Dovepress}

The manuscript management system is completely online and includes a very quick and fair peer-review system, which is all easy to use. Visit http://www.dovepress.com/testimonials.php to read real quotes from published authors. 